\title{
Effect of the chemical attack on the properties of cimentititous composites with partial substitution of ash from sugar cane bagasse in natura
}

\author{
Islane Santos ${ }^{1}$, João Pedro Lages Rodrigues ${ }^{1}$, Clareana Gusmão Ramos ${ }^{1}$, \\ Carolina Coelho Martuscelli ${ }^{1}$, Ugo Nogueira Castañon ${ }^{1}$, \\ Verônica Christina Corrêa Alves ${ }^{1}$, Gabriel Mendes Abreu ${ }^{1}$
}

\begin{abstract}
${ }^{1}$ Instituto de Ciência, Engenharia e Tecnologia, Universidade Federal dos Vales do Jequitinhonha e Mucuri ICET/UFVJM, Teófilo Otoni, CEP:39803-371, Minas Gerais, Brasil. E-mail: islanesal@gmail.com, joaopedro.ecv@gmail.com, claregusmao@live.com, carolina.martuscelli@ufvjm.edu.br, ugo.castanon@ufvjm.edu.br, veronicachristina@hotmail.com, gabrielmendesa@gmail.com.
\end{abstract}

\begin{abstract}
Seeking the reutilization of waste from agriculture and urban sources, studies have presented an option in the inclusion of such waste into new low-cost materials that are environmentally viable. One possibility is the reutilization of sugarcane bagasse ashes (SBA), the final waste in the productive process of the Brazilian alcohol sector. In addition to the behavior of materials with the use of SBA as additions in cement-based materials under normal environmental conditions, the study of the behavior of these materials when exposed to harsh environments is required. Thus, this project evaluated the properties, the compression strength and the bulk density of cement composites with partial replacement of cement by SBA without prior treatment. Also, it analyzed the weight loss and compressive strength of the composites subjected to environments with the presence of chloride ions. A factorial design was adopted to verify the influence of the addition of SBA $(5 \mathrm{wt} \%, 10 \mathrm{wt} \%$ and $15 \mathrm{wt} \%)$ and water/cement ratio $(0.45$ and 0.55$)$ in the studied properties. The interaction between the factors was significant. The values obtained from the compressive strength of the manufactured composites showed that it is possible to replace up to $15 \mathrm{wt} \%$ of cement for in natura SBA. After a chemical attack with an acid solution of $\mathrm{HCl} 30 \%$, it could be observed that all materials had a lower compressive strength, which can be explained by the high weight loss suffered by all composites. Based on the results of compressive resistance, density and weight loss after the attack, it was observed that the mechanical behavior of the composites in relation to the referential conditions were similar. This study showed that it is feasible, in accordance to the studied properties, to use these composites in promoting the partial replacement of cement by this type of waste and its reutilization.
\end{abstract}

Keywords: Reutilization of waste, composites, mechanical properties, chemical attack, sugarcane bagasse ashes.

\section{INTRODUCTION}

The necessity of energy generation from renewable resources, especially alcohol, boosted the development in the alcohol sector of Brazilian industry through the production of sugarcane. It is estimated that in Brazil a production of sugarcane processed in the 2015/16 harvest until October reached a total of 480.44 million tons [1].

The growth of ethanol and sugar production is directly related to the increase of volume of residues, the bagasse from sugarcane, that are left in this process. According to the National Electric Energy Agency [2] the bagasse from sugar cane is among the main biomass used for energy co-generation in thermoelectric plants, due to the already produced volume and the fact that the harvest coincide with the drought period in some regions of Brazil.

The Union of Sugar Cane Industry (UNICA) [3] states that with reference only to the bioelectricity of sugarcane, the sugarcane industry now holds $7 \%$ of the power in Brazil and almost $76 \%$ of the biomass source, being the third most important source of power generation in terms of installed capacity, behind only the water source and thermoelectric with natural gas.

According to surveys conducted by the FIES and CIESP [4] for each ton of bagasse that feeds the co- 
generation process, $25 \mathrm{~kg}$ of sugarcane bagasse ashes (SBA) are produced. These ashes are being used as fertilizer for crops, but with the large increase and accumulation, the destination becomes a problem to be faced. The ashes containing silicon dioxide have pozzolanic characteristics, depending on the burning conditions and the size of its grains $[5,6]$. Considering these characteristics, the SBA becomes an important material which may be used as fine aggregate or as partial replacement in cement-based materials [7-11].

In the search of the reutilization of SBA with its insertion in the production of pastes, mortars and concrete, it is necessary and indispensable to evaluate the behavior and the ability of these new materials to resist under normal conditions and when exposed to aggressive environments. Thus, this study aimed to evaluate the properties of compressive resistance, and density of cementitious composites with partial replacement of cement by SBA in natura, and evaluate the weight loss and compressive resistance when they are subjected to chemical attack acid ( $\mathrm{HCl} 30 \%)$.

\section{MATERIALS E METHODS}

The cementitious composites have as matrix phase one cementitious paste, and a dispersed phase consisting of ash from sugar cane bagasse. The cement used was Portland cement CPV ARI and was provided by Cauê industry. The sugar cane ash was obtained from Nutritiva Agroindustrial Ltda. company, located in Montes Claros - MG, Brazil.

The sugar cane ashes in natura were adopted in the preparation of the composites. The ashes were classified by the grain size, and were used the passers in the sieve with opening 80 US-Tyler. After the sieving, they were dried in an oven set at $60^{\circ} \mathrm{C}$ for 24 hours.

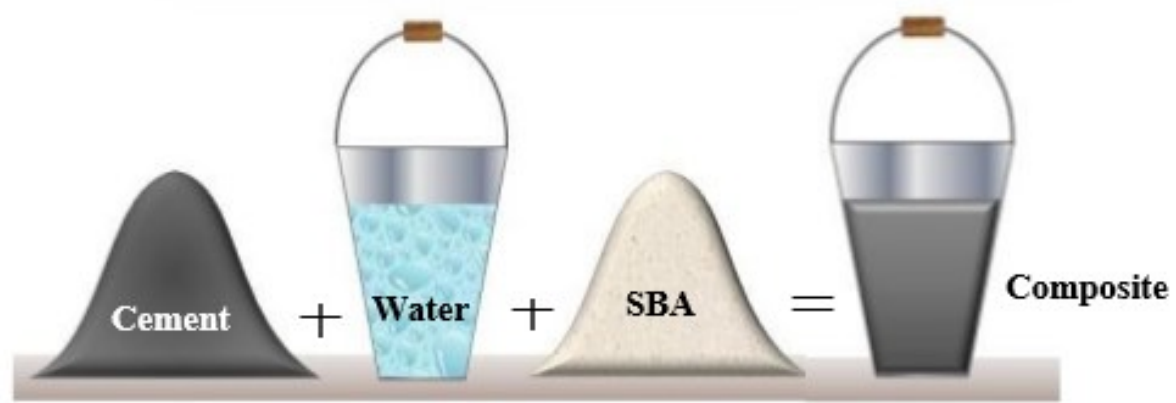

Figure 1: Composition of the studied material.

\subsection{The Experimental Design}

The statistical method of design of experiment (DOE) and analysis of variance (ANOVA) provides the meaning of each experimental factor in the studied answers. A full factorial design nk are realized to investigate all possible combinations of experimental factors (k) and their levels (n). The results of the nk factorial corresponds to the number of experimental conditions investigated [12].

In the present study used the statistical software Minitab version 16 for the processing and analysis of results, as of mentioned method.

A full factorial design was used, with all possible combinations of factor and their levels, setting 6 different conditions. The experimental factors and levels analyzed were: addition of ash $(5 \mathrm{wt} \%, 10 \mathrm{wt} \%, 15 \mathrm{wt} \%)$ and $\mathrm{w} / \mathrm{c}$ ratio $(0.45$ and 0.55$)$. Besides these, were manufactured two reference conditions to the proposed levels of w/c ratio and without cement replacement by ash. Table 1 shows the experimental conditions investigated.

The P-values indicate which factors have statistically significant effects. If the P-value is less than or equal to 0.05 , the effect is considered significant. When an interaction of factors showed significant P-value, then the interacting factors must be mutually considered and not in isolation [12]. 
Table 1: Experimental Conditions.

\begin{tabular}{|c|c|c|}
\hline \multirow{2}{*}{ Experimental conditions } & \multicolumn{2}{|c|}{ Factors } \\
\hline & Ash fraction (\%wt) & water/cement ratio \\
\hline $\mathrm{R} 1$ & - & 0.45 \\
\hline $\mathrm{R} 2$ & - & 0.55 \\
\hline $\mathrm{C} 1$ & 5 & 0.45 \\
\hline $\mathrm{C} 2$ & 10 & 0.45 \\
\hline $\mathrm{C} 3$ & 15 & 0.45 \\
\hline $\mathrm{C} 4$ & 5 & 0.55 \\
\hline $\mathrm{C} 5$ & 10 & 0.55 \\
\hline C6 & 15 & 0.55 \\
\hline
\end{tabular}

\subsection{Fabrication of Samples}

The fabrication of the samples was manually conducted by mixing the materials based on the experimental setup shown in table (Table 1). The specimens were fabricated using polymeric cylindrical molds of dimensions $25.6 \mathrm{~mm}$ diameter and $51.2 \mathrm{~mm}$ in height. Six samples and two replicates were made for mechanical testing and four samples were used for the bulk density calculate and for weight loss analysis. After 28 days of curing, the samples were removed from the molds and tested.

The chemical attack was made using hydrochloric acid $(\mathrm{HCl})$ in aqueous solution with concentration of $30 \%$. The composites were immersed in solution for 72 hours in a closed container and then washed in water to remove the excess of acid. So, they were dried in an oven at $60^{\circ} \mathrm{C}$ for 7 days.

The compressive strength tests were performed according to recommendations of the standard NBR 7215, using a digital electric press (brand Solocap) with maximum load of $1000 \mathrm{kN}$. The bulk density was determined by the ratio between the weight and volume of the dried sample (after $24 \mathrm{~h}$ in an oven at $60^{\circ} \mathrm{C}$ ). To determine the weight loss, the samples were weighed before and after the chemical attack.

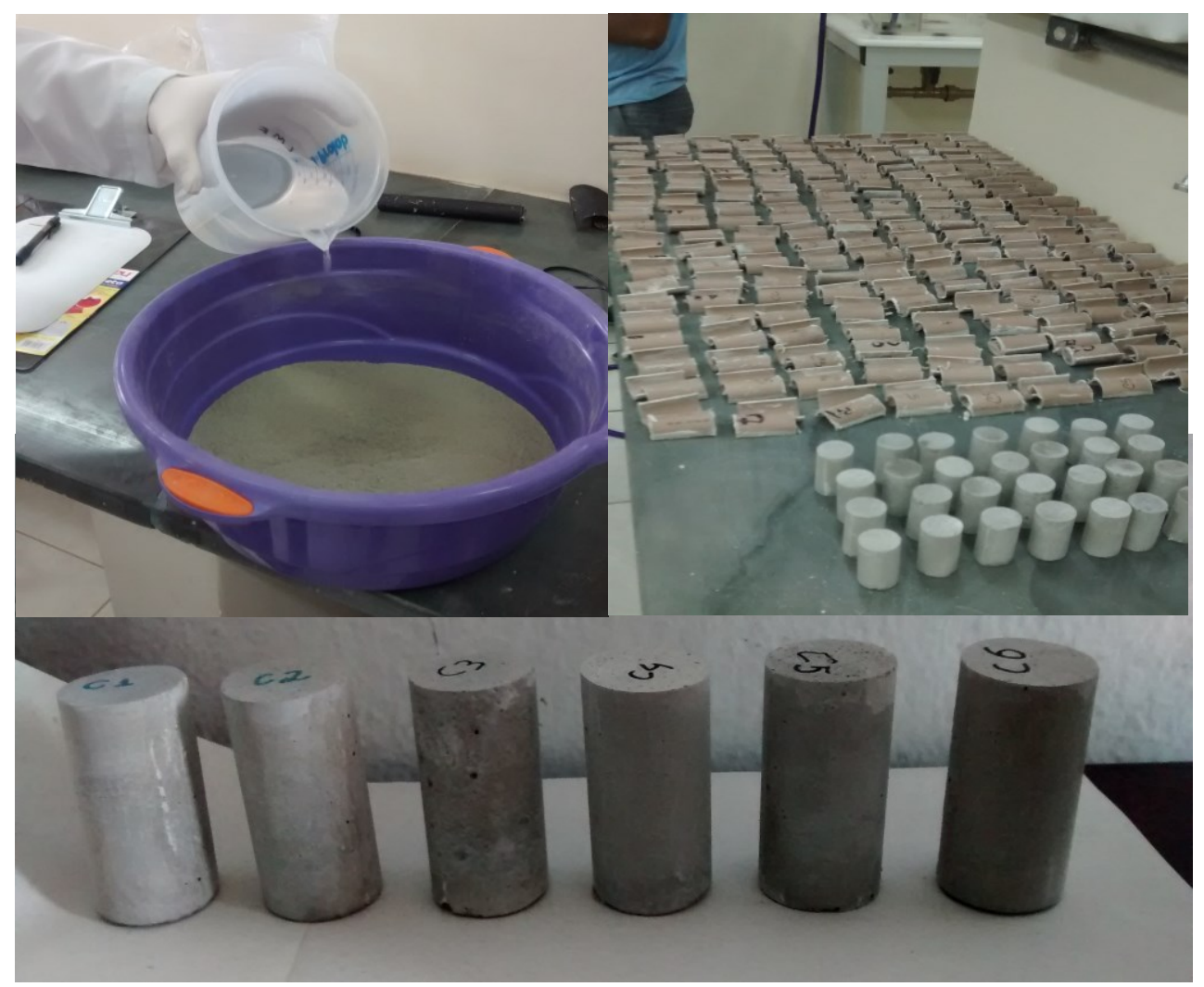

Figure 2: Fabrication of Samples 


\section{RESULTS AND DISCUSSION}

The table 2 shows the results of analysis of variance (ANOVA), for the average of the variables responses investigated to composite. It were used replication, making possible the obtainment of a more accurate estimate of the effects.

Table 2: Analysis of Variance (ANOVA).

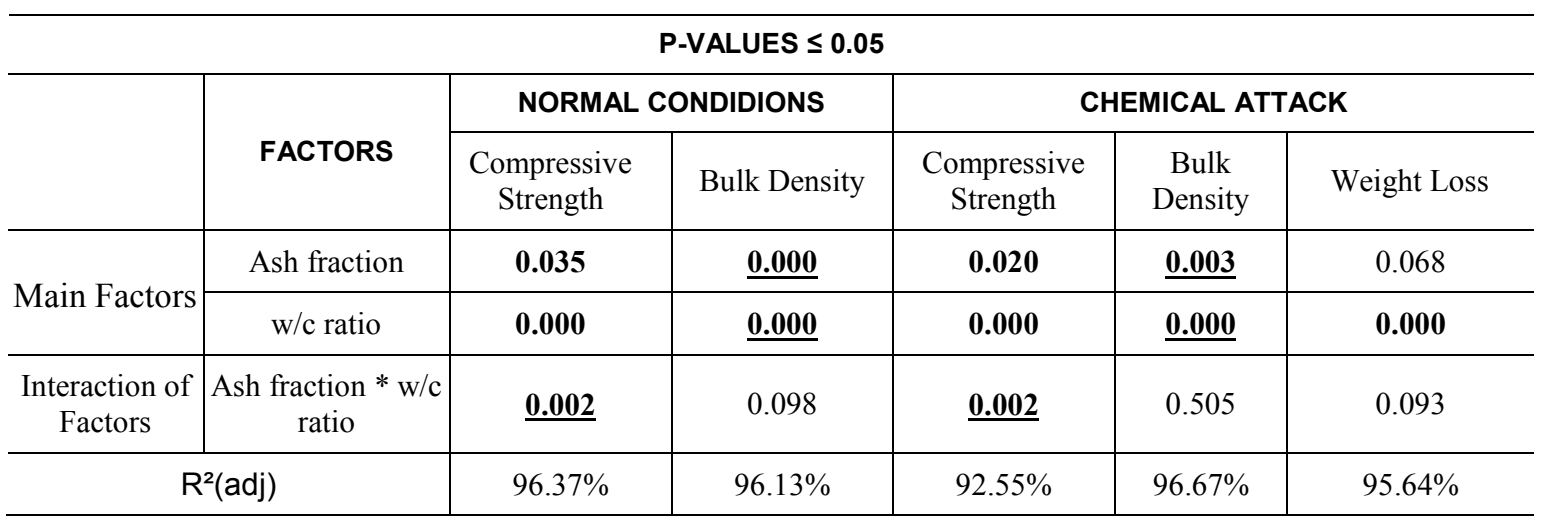

\subsection{Compressive Strength}

The P-value (0.002) underlined and bold in the table (Table 2) show that the interaction of ash fraction factors and relation $\mathrm{w} / \mathrm{c}$ were significant and therefore will be analyzed. The results for apparent density can also be seen in table 3 .

Table 3: Results of Compressive Strenght

\begin{tabular}{|c|c|c|c|c|}
\hline CONDITIONS & REPLICATE & $\begin{array}{l}\text { COMPRESSIVE } \\
\text { STRENGTH (MPa) }\end{array}$ & $\begin{array}{c}\text { STANDARD } \\
\text { DEVIATION } \\
\text { (MPa) }\end{array}$ & $\begin{array}{c}\text { COEFFICIENT OF } \\
\text { VARIATION }\end{array}$ \\
\hline \multirow{2}{*}{ R1 } & 1 & 30.489 & 2.9098 & 0.0954 \\
\hline & 2 & 28.211 & 1.8904 & 0.0670 \\
\hline \multirow{2}{*}{ C1 } & 1 & 26.318 & 2.8454 & 0.1081 \\
\hline & 2 & 25.462 & 3.7149 & 0.1459 \\
\hline \multirow{2}{*}{$\mathrm{C} 2$} & 1 & 27.051 & 6.7054 & 0.2479 \\
\hline & 2 & 28.089 & 6.3061 & 0.2245 \\
\hline \multirow{2}{*}{$\mathrm{C} 3$} & 1 & 28.272 & 5.9591 & 0.2108 \\
\hline & 2 & 27.347 & 6.2877 & 0.2299 \\
\hline \multirow{2}{*}{ R2 } & 1 & 24.869 & 3.8218 & 0.1537 \\
\hline & 2 & 23.682 & 3.4751 & 0.1467 \\
\hline \multirow{2}{*}{$\mathrm{C} 4$} & 1 & 23.630 & 4.2740 & 0.1809 \\
\hline & 2 & 21.204 & 4.3939 & 0.2072 \\
\hline \multirow{2}{*}{ C5 } & 1 & 17.723 & 2.2956 & 0.1295 \\
\hline & 2 & 16.318 & 4.6275 & 0.2836 \\
\hline \multirow{2}{*}{ C6 } & 1 & 16.405 & 2.8264 & 0.1723 \\
\hline & 2 & 15.707 & 3.5822 & 0.2281 \\
\hline
\end{tabular}

The substitution of cement for SBA in mass fractions $5 \mathrm{wt} \%, 10 \mathrm{wt} \%$ e $15 \mathrm{wt} \%$, resulted in a decrease in compressive strength in $14.74 \%, 9.21 \%$ and $8.42 \%$ respectively for $\mathrm{R} 1$, and $18.33 \%, 38.02 \%$ and $41.53 \%$ 
respectively for R2. Thus it can be seen that the condition 3 (C3) had higher mean values of compressive strength.

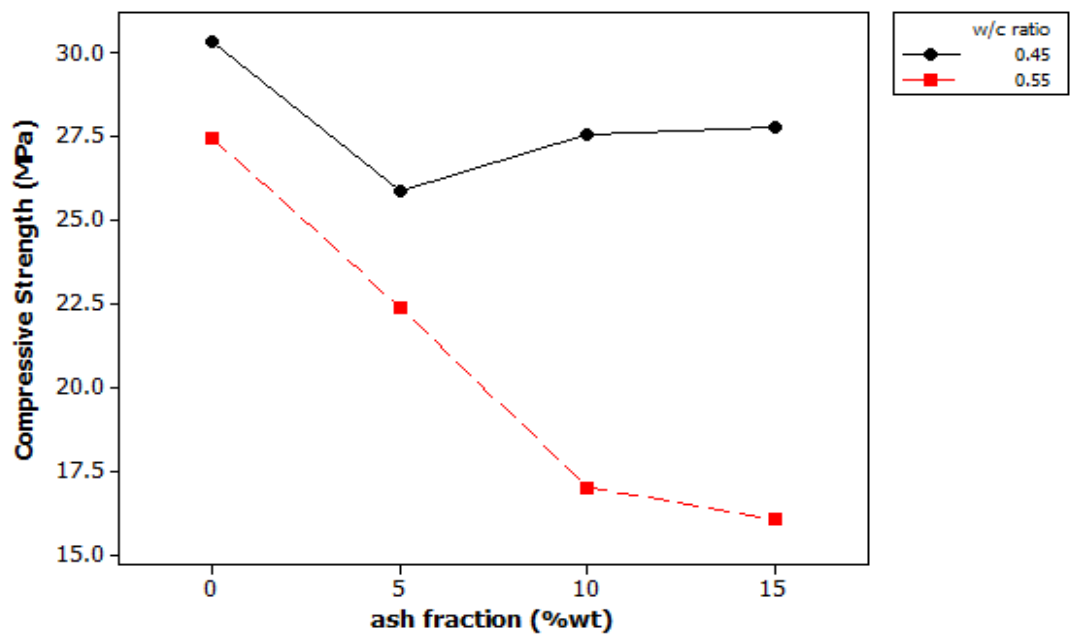

Figure 3: Plot of the interaction effect between ash substitution and w/c ratio on the mean compressive strength.

The figure 3 shows that the composites obtained with the w/c ratio of 0.45 presented higher mean value of compressive strength for all percent of ash analyzed. Inverse behavior was observed when using the $\mathrm{w} / \mathrm{c}$ ratio of 0.55 , which can be explained by the excess water which enables exudation in the manufacturing process. Thus, there is an increase in the porosity of the material, resulting in the loss of their resistance, similar behavior exhibited by conventional cementitious binders.

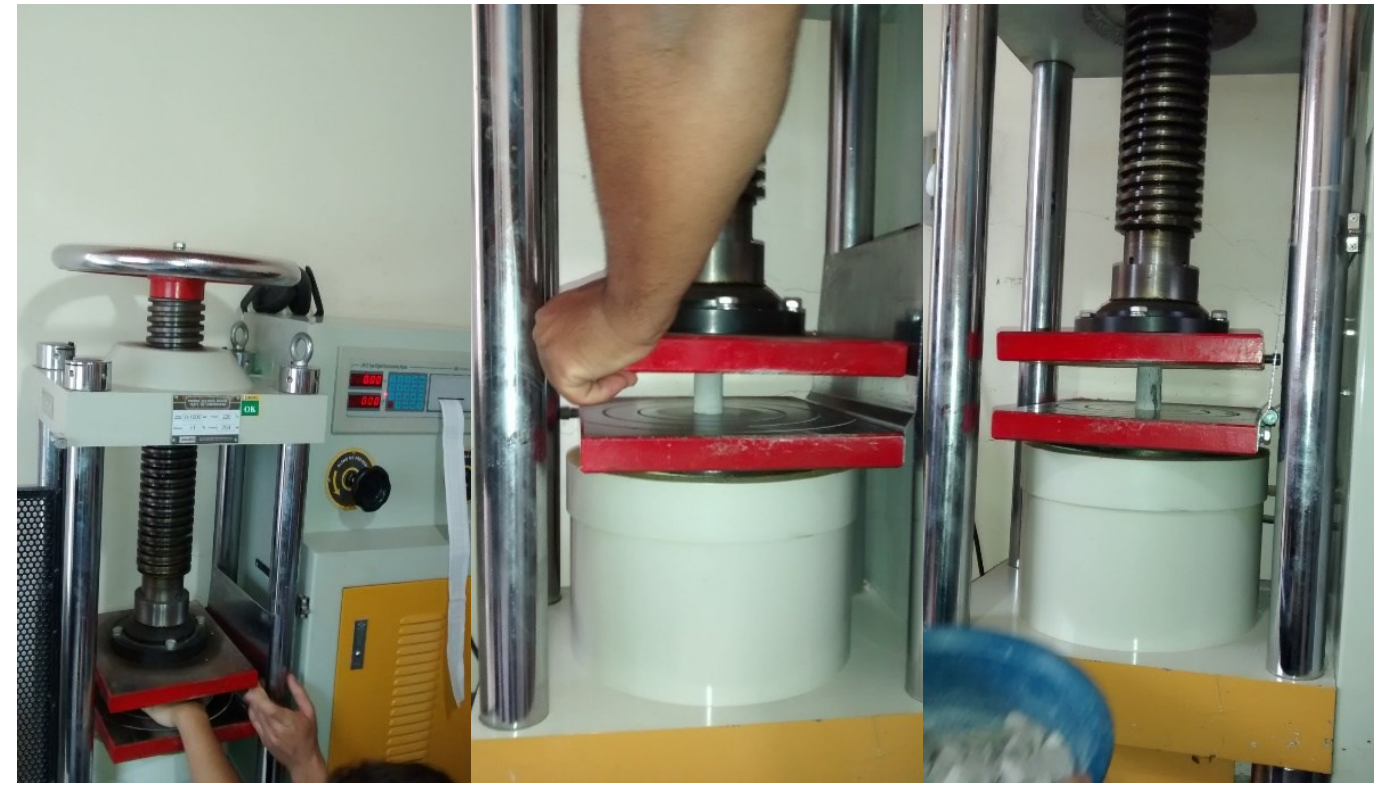

Figure 4: Compression strength test.

\subsection{Bulk Density}

The main factors, w/c ratio and ashes fraction, have a significant effect on the bulk density, as can be observed by the P-values, shown in table (Table 2), under 0.05. Already the interaction of factors relationship $\mathrm{w} / \mathrm{c}$ and ash fraction was not significant, so the main effects were analyzed individually. The results for bulk density as can be seen in table 4 . 
Table 4: Results of Bulk Density

\begin{tabular}{|c|c|c|c|c|}
\hline CONDITIONS & REPLICATE & $\begin{array}{l}\text { BULK DENSITY } \\
\qquad\left(\mathrm{g} / \mathrm{cm}^{3}\right)\end{array}$ & $\begin{array}{l}\text { STANDARD DEVIATION } \\
\left(\mathrm{g} / \mathrm{cm}^{3}\right)\end{array}$ & $\begin{array}{c}\text { COEFFICIENT OF } \\
\text { VARIATION }\end{array}$ \\
\hline \multirow{2}{*}{ R1 } & 1 & 1.828 & 0.048 & 0.0263 \\
\hline & 2 & 1.854 & 0.0504 & 0.0272 \\
\hline \multirow{2}{*}{ C1 } & 1 & 1.837 & 0.0122 & 0.0066 \\
\hline & 2 & 1.852 & 0.0221 & 0.0119 \\
\hline \multirow{2}{*}{ C2 } & 1 & 1.814 & 0.0249 & 0.0137 \\
\hline & 2 & 1.833 & 0.0221 & 0.0121 \\
\hline \multirow{2}{*}{$\mathrm{C} 3$} & 1 & 1.800 & 0.0505 & 0.0281 \\
\hline & 2 & 1.793 & 0.0723 & 0.0403 \\
\hline \multirow{2}{*}{$\mathbf{R 2}$} & 1 & 1.658 & 0.0243 & 0.0147 \\
\hline & 2 & 1.707 & 0.0517 & 0.0303 \\
\hline \multirow{2}{*}{$\mathrm{C} 4$} & 1 & 1.789 & 0.0034 & 0.0019 \\
\hline & 2 & 1.791 & 0.0748 & 0.0418 \\
\hline \multirow{2}{*}{ C5 } & 1 & 1.734 & 0.0611 & 0.0352 \\
\hline & 2 & 1.740 & 0.0686 & 0.0394 \\
\hline \multirow{2}{*}{ C6 } & 1 & 1.723 & 0.0454 & 0.0264 \\
\hline & 2 & 1.738 & 0.0287 & 0.0165 \\
\hline
\end{tabular}

Figure 5 shows the graph of the main effect w/c on the bulk density of the composite. When comparing the average bulk densities for the $\mathrm{w} / \mathrm{c}$ ratio, it were observed that the composites with $\mathrm{w} / \mathrm{c} 0.55$ presents a reduction of $3.79 \%$ compared to values obtained with w/c ratio of 0.45 . The increase in pore due to the excessive amount of water can explain the reduction in density of materials as observed, proposing that the relation w/c of 0.45 was enough for cement complete hidratation.

In the figure 6 it is possible to analyze the main effect of gray fraction in the density of the composite. It is observed that the higher the cement replacement for ashes, the lower the density displayed, it can be explained by difference in density between the cement and the replacement material, once the sugar cane ash has lower bulk density than the cement.

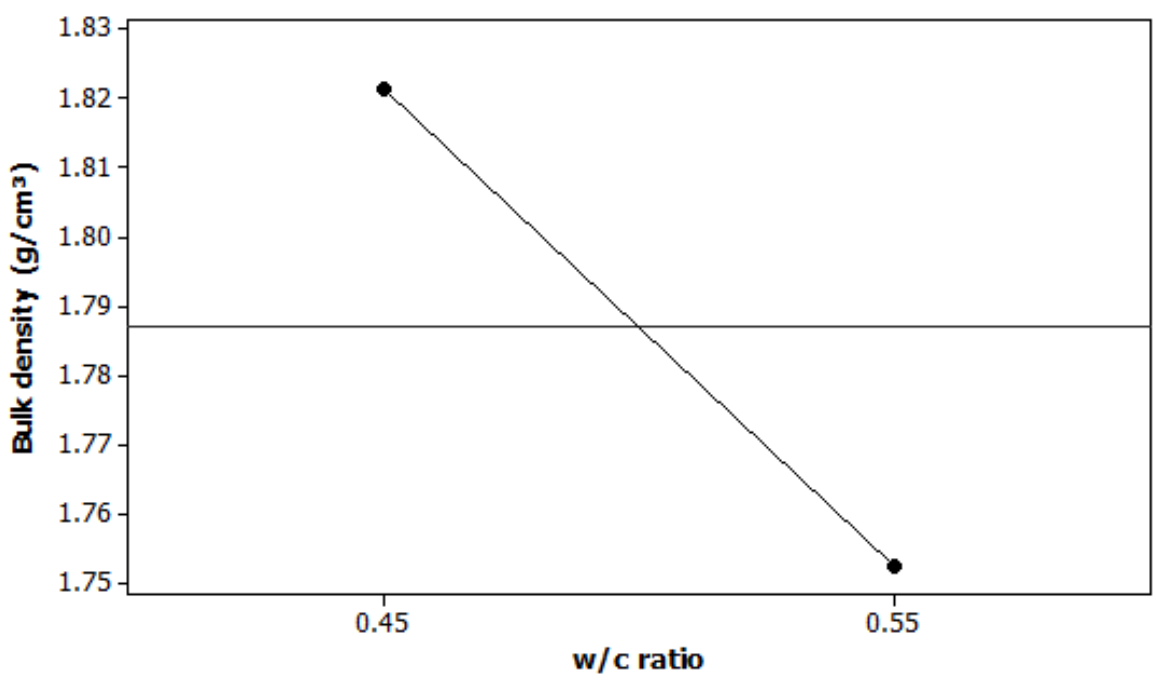

Figure 5: Main effect plot of w/c ratio for the mean bulk density. 


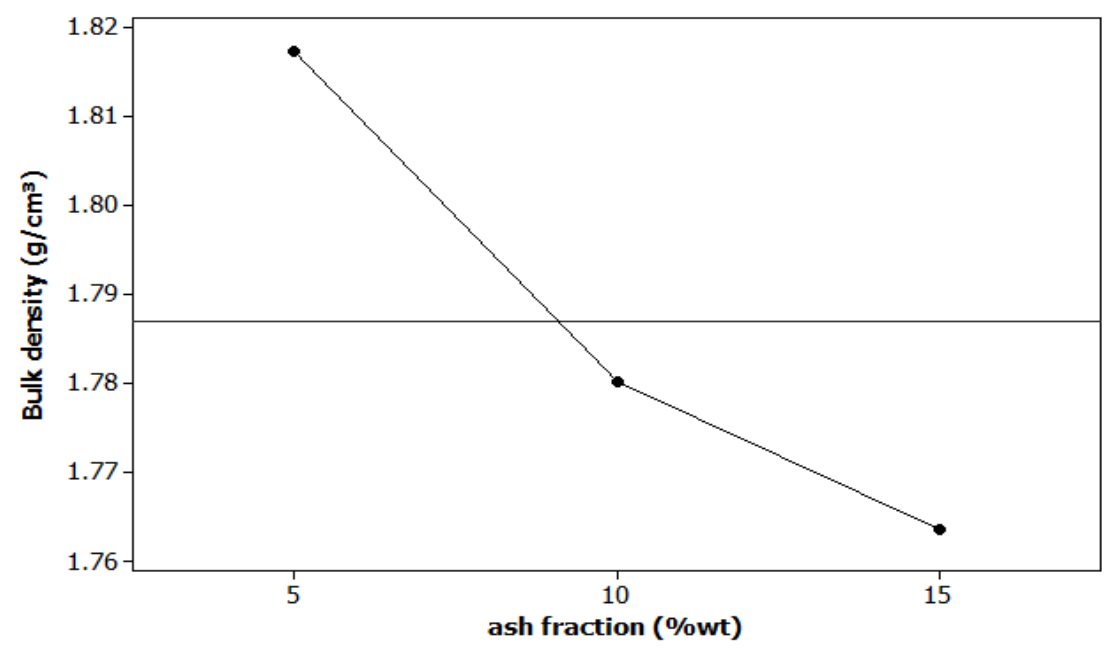

Figure 6: Main effect plot of ash fraction for the mean bulk density.

\subsection{Compressive Strength after Chemical Attack}

The compressive strength reductions presented after chemical attack to the references R1 and R2 analyzed were approximately $19 \%$ and $13 \%$. The conditions C3 and C5 were approximately maximum 35\% and minimum $10 \%$ of reduction of the compressive strength after the chemical attack, compared to the values presented before the attack for the studied composites. as can be seen in table 5 .

Table 5: Results of Compressive Strenght after Chemical Attack

\begin{tabular}{|c|c|c|c|c|}
\hline CONDITIONS & REPLICATE & $\begin{array}{l}\text { COMPRESSIVE } \\
\text { STRENGTH (MPa) }\end{array}$ & STANDARD DEVIATION (MPa) & $\begin{array}{c}\text { COEFFICIENT OF } \\
\text { VARIATION }\end{array}$ \\
\hline \multirow{2}{*}{ R1 } & 1 & 26.571 & 0.8021 & 0.0302 \\
\hline & 2 & 26.754 & 1.0613 & 0.0397 \\
\hline \multirow{2}{*}{ C1 } & 1 & 20.384 & 1.8404 & 0.0903 \\
\hline & 2 & 23.141 & 3.1064 & 0.1342 \\
\hline \multirow{2}{*}{$\mathrm{C} 2$} & 1 & 25.768 & 2.4920 & 0.0967 \\
\hline & 2 & 24.695 & 2.8966 & 0.1173 \\
\hline \multirow{2}{*}{$\mathbf{C 3}$} & 1 & 19.110 & 3.6702 & 0.1921 \\
\hline & 2 & 19.145 & 0.0494 & 0.0026 \\
\hline \multirow{2}{*}{$\mathbf{R} 2$} & 1 & 19.415 & 1.0736 & 0.0553 \\
\hline & 2 & 20.541 & 2.6655 & 0.1298 \\
\hline \multirow{2}{*}{$\mathbf{C 4}$} & 1 & 19.058 & 4.5536 & 0.2389 \\
\hline & 2 & 19.389 & 0.4565 & 0.0235 \\
\hline \multirow{2}{*}{ C5 } & 1 & 14.619 & 2.6676 & 0.1825 \\
\hline & 2 & 12.653 & 1.5302 & 0.1209 \\
\hline \multirow{2}{*}{ C6 } & 1 & 16.414 & 2.9354 & 0.1788 \\
\hline & 2 & 15.070 & 1.1477 & 0.0762 \\
\hline
\end{tabular}


The composites showed maximum percentage reduction least $23 \%$ and $4 \%$ in the mean compressive strength of the composite after etching with respect to the references.

The P-value (0.002) underlined and in bold in table 2 show that the interaction of ash fraction factors and w/c ratio was significant in post chemical attack compressive strength response.

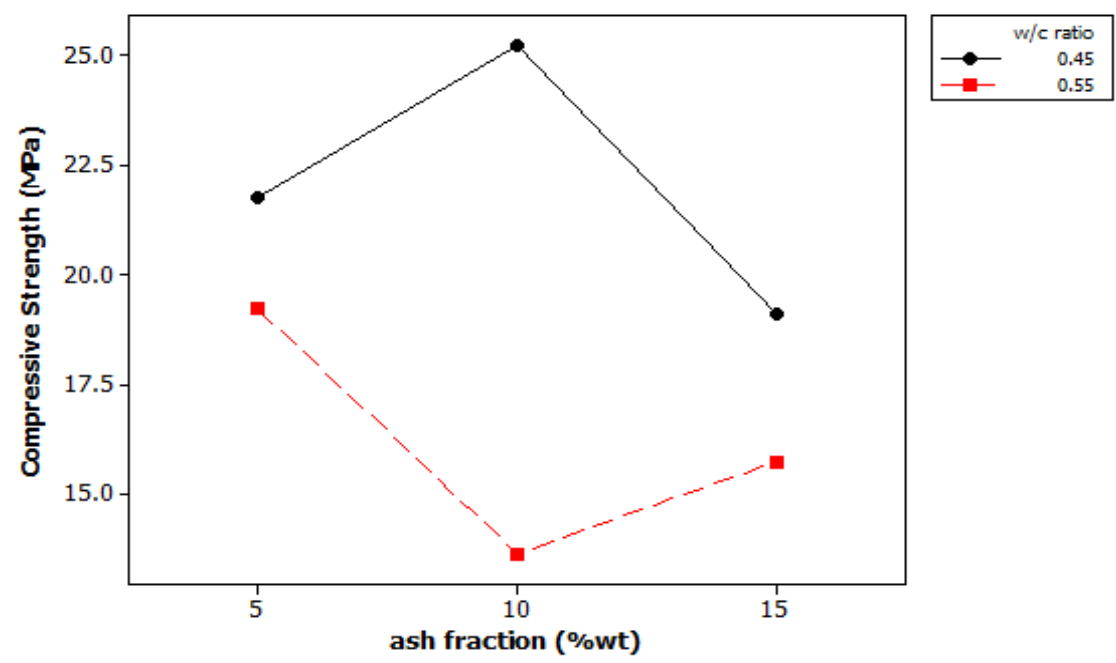

Figure 7: Plot of the interaction effect between ash substitution and w/c ratio on the mean compressive strength after chemical attack.

Figure 7 shows that composites with $5 \mathrm{wt} \%$ substitution fractions showed higher compression resistance values for the two levels of the w/c studied when compared to composites with $15 \mathrm{wt} \%$ SBA. An increased compressive strength in composites with $10 \mathrm{wt} \%$ SBA and the w/c of 0.45 , equating the composite consisting of $5 \mathrm{wt} \%$ and $15 \mathrm{wt} \%$ cement replacement by SBA was observed, however the materials made with respect to w/c 0.55 showed opposite behavior to that fraction of replacement. The compressive strength values after etching for all composites constituted ratio w/c of 0.55 were lower than those presented for the relationship 0.45 , similar behavior to present for the composite before being submitted to chemical attack.

\subsection{Bulk Density after Chemical Attack}

The volumetric density decreases presented after chemical attack for analyzed references R1 and R2 were approximately $13 \%$ and $2 \%$, conditions C6 and C1 have presented about $19 \%$ of maximum values and $12 \%$ of minimum values reduction of this property after chemical attack, compared to values presented before the attack for the studied composites. as can be seen in table 6 .

Table 6: Results of Bulk Density after Chemical Attack

\begin{tabular}{c|c|c|c|c}
\hline \multirow{2}{*}{ CONDITIONS } & REPLICATE & $\begin{array}{c}\text { BULK DENSITY } \\
\left(\mathbf{g} / \mathbf{c n}^{3}\right)\end{array}$ & $\begin{array}{c}\text { STANDARD DEVIATION } \\
\left(\mathbf{g} / \mathbf{c m}^{3}\right)\end{array}$ & $\begin{array}{c}\text { COEFFICIENT OF } \\
\text { VARIATION }\end{array}$ \\
\hline \multirow{2}{*}{$\mathbf{R} 1$} & 1 & 1.612 & 0.0027 & 0.0017 \\
\cline { 2 - 5 } & 2 & 1.214 & 0.0156 & 0.0129 \\
\hline \multirow{2}{*}{$\mathbf{C 1}$} & 1 & 1.614 & 0.0145 & 0.0090 \\
\cline { 2 - 5 } & 2 & 1.621 & 0.0097 & 0.0060 \\
\hline \multirow{2}{*}{$\mathbf{C 2}$} & 1 & 1.574 & 0.0496 & 0.0315 \\
\cline { 2 - 5 } & 2 & 1.545 & 0.0683 & 0.0442 \\
\cline { 2 - 5 } & 1 & 1.545 & 0.0538 & 0.0348 \\
\hline
\end{tabular}




\begin{tabular}{c|c|c|c|c}
\hline \multirow{2}{*}{$\mathbf{R 2}$} & 1 & 1.711 & 0.0803 & 0.0469 \\
\cline { 2 - 5 } & 2 & 1.630 & 0.0768 & 0.0471 \\
\hline \multirow{3}{*}{$\mathbf{C 4}$} & 1 & 1.460 & 0.0282 & 0.0193 \\
\cline { 2 - 5 } & 2 & 1.483 & 0.0270 & 0.0182 \\
\hline \multirow{2}{*}{$\mathbf{C 5}$} & 1 & 1.428 & 0.0035 & 0.0025 \\
\cline { 2 - 5 } & 2 & 1.429 & 0.0254 & 0.0178 \\
\hline \multirow{2}{*}{ C6 } & 1 & 1.441 & 0.0353 & 0.0245 \\
\cline { 2 - 5 } & 2 & 1.430 & 0.0369 & 0.0258 \\
\hline
\end{tabular}

The composites have presented maximum percentage reduction of about $14 \%$ and minimum of $2 \%$ in the average density of the composite after chemical attack according to the references. By analyzing the effects of the chemical attack on the volumetric density, it is observed that the P-value $(0.000$ and 0.003$)$ underlined and in bold in the table 2 becomes statistically significant the main factors, especially the interaction did not show statistically significant results.

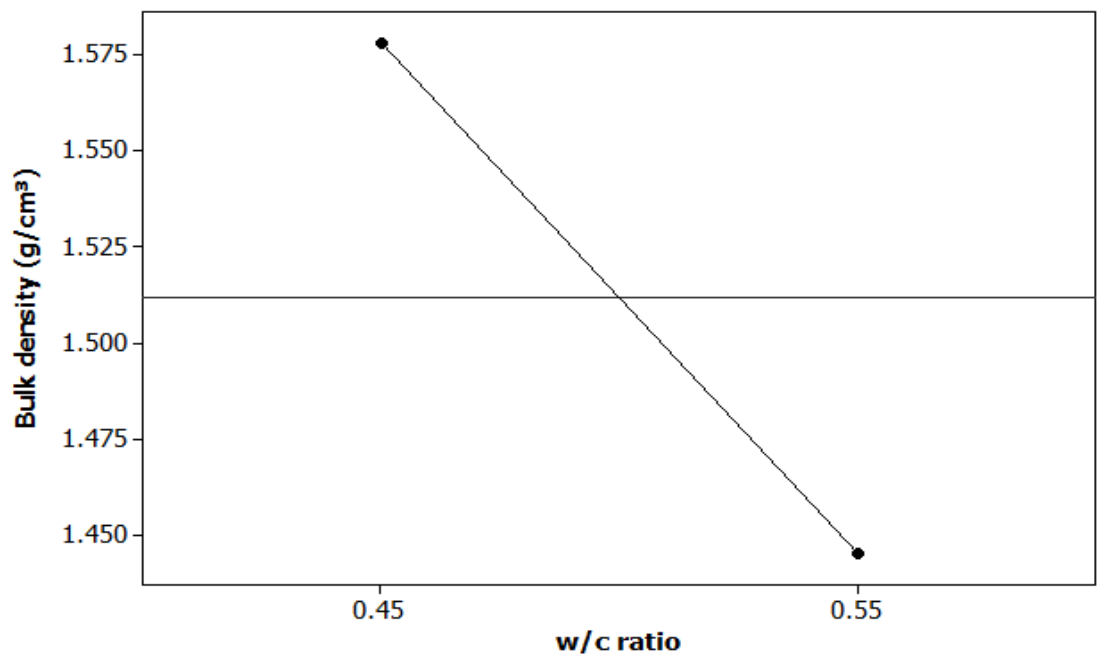

Figure 8: Main effect plot of w/c ratio for the mean bulk density after chemical attack.

It is noted that the increasing of the w/c ratio has provided decrease in the values of the volumetric density of the composite after chemical attack as shows figure 8 . This effect can be explained by the greater weight loss shown by the composites with w/c ratio of 0.55 , of this material when compared to composites with the w/c ratio of 0.45 .

The figure 8, shows that materials with lower mass replacement by the SBA cement, have presented higher densities when compared to composites of higher amounts of analyzed replacement fraction, this result is analogous to that reported in bibliography [13], which attributes this decrease to increased levels of voids and the relative density of the ash towards the cement. This behavior is similar to that observed in the volumetric density of the composites before the chemical attack.

For analysis with respect to the ash fraction factor, the composite of $5 \mathrm{wt} \%$ has obtained minimum of density with respect to the reference not chemically attacked, because of the higher stability of the cement with the presence of hydrocyanic acid $(\mathrm{HCl})$ in the solution. 


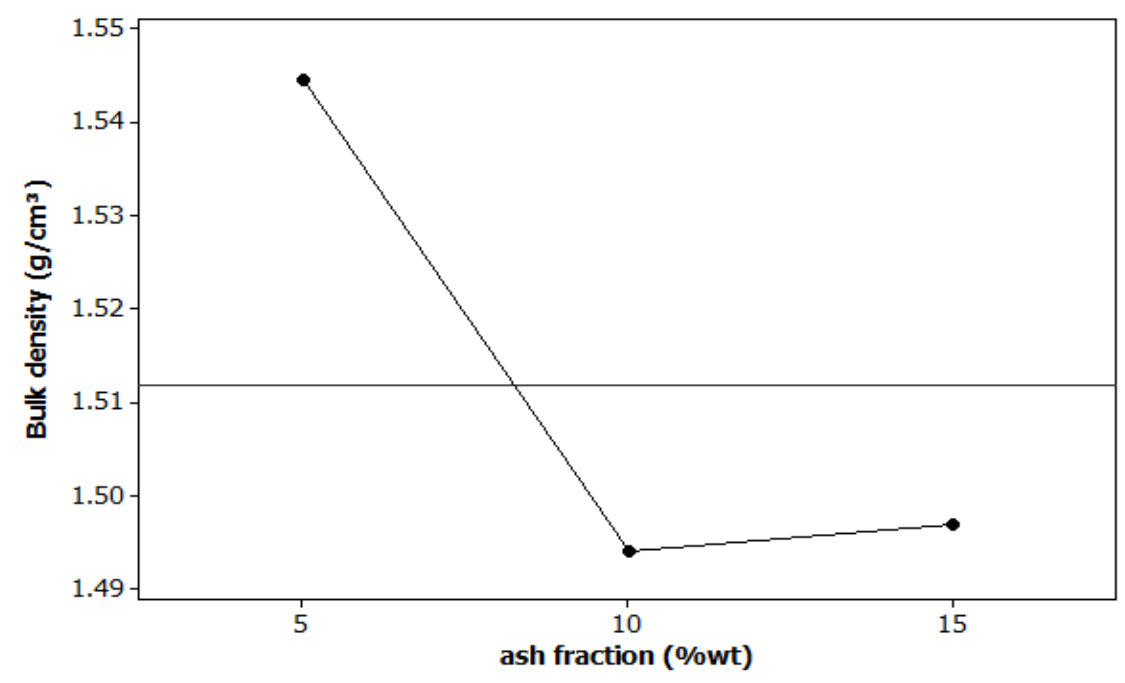

Figure 9: Main effect plot of ash fraction for the mean bulk density after chemical attack.

\subsection{Weight Loss}

By analyzing the Table 2, it is seen that only the main effect $\mathrm{w} / \mathrm{c}$ ratio was significant about the weight loss of composites investigated.

The increase in weight loss of the composites analyzed for its reference, ranged from $0.29 \%$ to $10.87 \%$ for R1 and between $5.78 \%$ and $11.63 \%$ for R2. Since the condition 1 (C1) showed less weight loss, similar to the reference condition, as can be seen in Table 7.

Table 7: Results of Weight Loss

\begin{tabular}{|c|c|c|c|c|}
\hline CONDITIONS & REPLICATE & $\begin{array}{c}\text { WEIGHT LOSS } \\
(\%)\end{array}$ & $\begin{array}{l}\text { STANDARD DEVIATION } \\
(\%)\end{array}$ & $\begin{array}{l}\text { COEFFICIENT OF } \\
\text { VARIATION }\end{array}$ \\
\hline \multirow{2}{*}{ R1 } & 1 & 14.953 & 0.2569 & 0.0172 \\
\hline & 2 & 15.157 & 0.2882 & 0.0190 \\
\hline \multirow{2}{*}{ C1 } & 1 & 15.268 & 0.3829 & 0.0251 \\
\hline & 2 & 14.797 & 0.2825 & 0.0191 \\
\hline \multirow{2}{*}{$\mathrm{C} 2$} & 1 & 15.964 & 0.7423 & 0.0465 \\
\hline & 2 & 16.455 & 1.1927 & 0.0725 \\
\hline \multirow{2}{*}{$\mathrm{C} 3$} & 1 & 16.286 & 1.0207 & 0.0627 \\
\hline & 2 & 16.579 & 0.4144 & 0.0250 \\
\hline \multirow{2}{*}{$\mathbf{R} 2$} & 1 & 19.109 & 1.0399 & 0.0544 \\
\hline & 2 & 18.623 & 2.9411 & 0.1579 \\
\hline \multirow{2}{*}{ C4 } & 1 & 19.496 & 0.3141 & 0.0161 \\
\hline & 2 & 19.903 & 0.3002 & 0.0151 \\
\hline \multirow{2}{*}{ C5 } & 1 & 20.613 & 1.1124 & 0.0540 \\
\hline & 2 & 20.427 & 2.1801 & 0.1067 \\
\hline \multirow{2}{*}{ C6 } & 1 & 19.028 & 0.4774 & 0.0251 \\
\hline & 2 & 20.298 & 1.7962 & 0.0885 \\
\hline
\end{tabular}


The figure 10 shows the graphic of main effect w/c about the weight loss of the composites submitted to chemical attack.

The increase in $25.01 \%$ of the weight loss observed in the conditions with w/c ratio of 0.55 is possibly due to the increased availability of chloride ions because of the high porosity of the material.

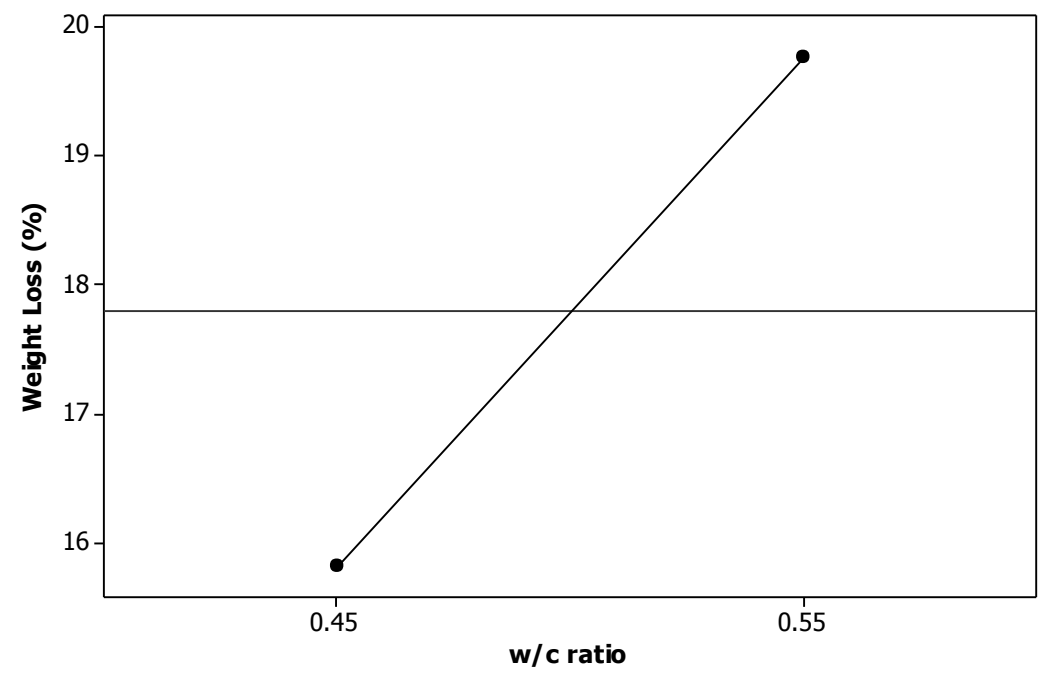

Figure 10: Main effect plot of w/c ratio for the weight loss.

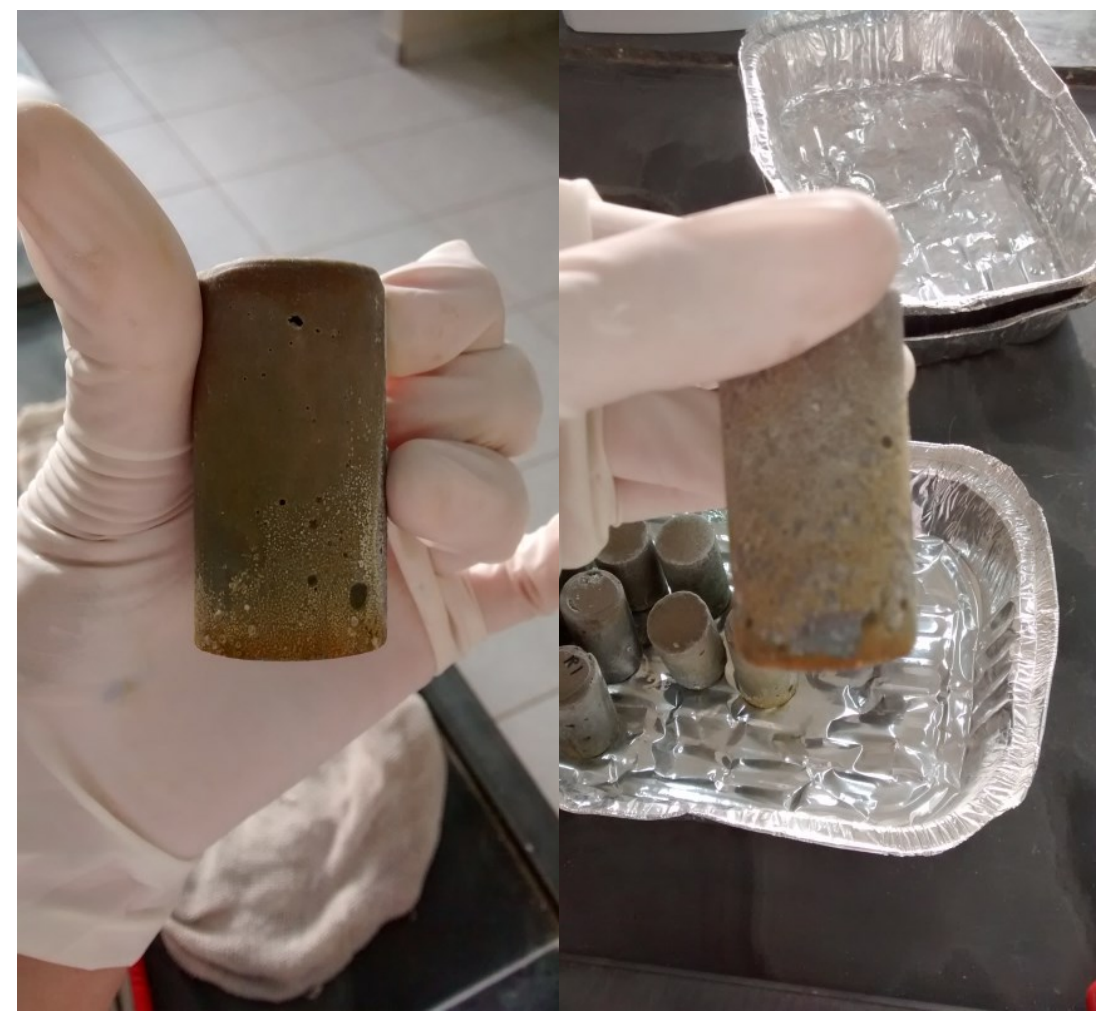

Figure 11: Samples after chemical attack. 


\section{CONCLUSIONS}

This paper investigates the effect of substitution of sugarcane bagasse ash in cement composites, considering the influence of $\mathrm{w} / \mathrm{c}$ ratio. The values obtained for the response variables of manufactured composites showed that replacement of up to $15 \mathrm{wt} \%$ of cement by SBA in nature is possible. The addition of ashes in the compound causes a general decrease of the parameters analyzed. The increase in water in the ratio w/c also negatively affect the results. However, it can be seen that the compressive strength of the samples made with $15 \mathrm{wt} \%$ of ash and the ratio w/c 0.45 showed very little variation compared to baseline condition, which shows that the material it has a behavior close to optimal for this type of composite. After the chemical attack which was performed with an acid solution of $30 \% \mathrm{HCl}$, it was observed that all the materials had lower resistance to compression, which can be explained by the high weight loss suffered by all composites. However, from the results of compressive strength, density and weight loss after the attack, it was observed that the mechanical behavior of the composites with respect to the reference conditions were similar. This study showed that with the use of these composites is possible promoting the partial replacement of cement by this type of waste from its reuse.

\section{BIBLIOGRAPHY}

[1] AQUINO, D.F. CONAB - COMPANHIA NACIONAL DE ABASTECIMENTO, http://www.conab.gov.br/OlalaCMS/uploads/arquivos/15_11_20_17_54_30_cana_de_acucar_outubro_2015. pdf. Acessado em junho de 2016.

[2] ANEEL - Agência Nacional de Energia Elétrica, Atlas de Energia Elétrica do Brasil, Editora Brasília, 2008.

[3] ÚNICA - União da Indústria de Cana-de-Açúcar, A bioeletricidade da cana em números. 2017. Disponível em: <www.unica.com.br/download.php?idSecao=17\&id=38583365>. Acessado em maio de 2017.

[4] FIESP/CIESP, Ampliação da oferta de energia através da biomassa (bagaço da cana-de-açúcar), São Paulo, FIESP/CIESP, 2001.

[5] PAULA, M.O., Potencial da cinza do bagaço de cana-de açúcar como material de substituição parcial de cimento Portland, Dissertação de M.Sc., UFV, Viçosa, MG, Brasil, 2006.

[6] NUNES, I.H.S., VANDERLEI, R.D., SECCHI, M., et al., "Estudo das características físicas e químicas da cinza do bagaço de cana-de-açúcar para uso na construção”, Revista Tecnológica, v. 17, n. 1, pp. 39-48, 2008.

[7] PAYA, M.V. J, MONZO, J, BORRACHERO, M.V., et al., "Sugar-cane bagasse ash (SCBA): studies on its properties for reusing in concrete production", Journal of Chemical Technology and Biotechnology, v. 77, i. 3 pp. 321-325, 2002.

[8] LIMA, S.A., SALES, A., CORDEIRO, S.G.F., PEREIRA, M.G.F., “Análise de contaminantes em concretos produzidos com a cinza do bagaço de cana-de-açúcar em substituição ao agregado miúdo", In: $53^{\circ}$ IBRACON (Congresso Brasileiro de Concreto), Florianópolis, SC, 2011.

[9] LIMA, S.A., SALES, A., MORETTI, J.P., et al., “Análise de argamassas confeccionadas com a cinza do bagaço da cana de açúcar em substituição ao agregado miúdo", Revista Tecnológica, Edição Especial ENTECA, pp. 87-97, 2009.

[10] SOUSA, L.R.L., FIGUEIREDO, E.P., RÊGO, J.H.S., "Caracterização de compósitos de cimento com substituição de cinzas de bagaço de cana-de-açúcar (CBC) em diferentes teores”, In: $51^{\circ}$ IBRACON (Congresso Brasileiro de Concreto), Fortaleza, CE, Brasil, 2010.

[11] SOUTO, J.M.F., VANDERLEI, R.D., NUNES, I.H.S., "Avaliação da cinza do bagaço de cana-deaçúcar em substituição parcial de cimento Portland na produção de concretos", In: $51^{\circ}$ IBRACON (Congresso Brasileiro de Concreto), Curitiba, SP, 2009.

[12] WERKEMA, M.C.C., AGUIAR, S., "Planejamento e análise de experimentos: como identificar e avaliar as principais variáveis influentes em um processo", Belo Horizonte, Fundação Christiano Ottoni, Escola de Engenharia da UFMG, 1996.

[13] SILVA, R. B., FONTES, C.M.A., LIMA, P.R.L., et al., "Cinzas de biomassa geradas na agroindústria do cacau: caracterização e uso em substituição ao cimento", Ambiente construído, v.15, n.4, pp.321-334, 2015.

[14] POGGIALI, F.S. J., Desempenho de microconcretos fabricados com cimento portland com adições de cinza de bagaço de cana-de-açúcar, Dissertação de M.Sc., UFMG, Belo Horizonte, MG, Brasil, 2010. 
SANTOS, I.; RODRIGUES, J.P.L.;RAMOS, C.G.; MARTUSCELLI, C.C.; CANTAÑON, U.G.; ALVES, V.C.C.; ABREU, G.M. revista Matéria, v.22, n.2, 2017.

[15] FERNANDES, S.E., Concreto com adição de cinza de bagaço de cana-de-açúcar, Dissertação de M.Sc., UNESP, São Paulo, SP, Brasil, 2014. 